See discussions, stats, and author profiles for this publication at: https://www.researchgate.net/publication/337945426

\title{
Survival modelling of Australian politicians
}

Article · December 2019

DOI: $10.1080 / 00323187.2019 .1701948$

\section{CITATIONS}

0

2 authors:

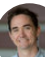

Marc West

Defence Innovation Network NSW

20 PUBLICATIONS 27 CITATIONS

SEE PROFILE

Some of the authors of this publication are also working on these related projects:

Survival Analysis View project

Pulsed Oscillating Mass Spectrometer View project
Bernard Kachoyan

UNSW Sydney

16 PUBLICATIONS 123 CITATIONS

SEE PROFILE 
This is a preprint of an article published by Taylor \& Francis in Political Science on 15/12/2019 available online:

https://www.tandfonline.com/doi/abs/10.1080/00323187.2019.1701948

\title{
Survival modelling of Australian politicians
}

\section{Marc Westa and Bernard Kachoyanb*}

\begin{abstract}
Are Australian political leaders an endangered species? A survival analysis of Australian politicians shows that modern leaders are having almost as tough a time as leaders were in the early days of Australian politics. This article examines the tenures of Prime Ministers and Federal Opposition Leaders to show that while the leadership turnover of the last decade has been high, the modern era is not unlike the Australian parliament after 1901, albeit for different reasons. The parliamentary tenures of members of the House of Representatives and the Senate, male and female members of both houses, and Labor and Liberal leaders have been compared using the survival analysis technique, and while simple statistical tests and descriptors may show little overall difference between the various survival curves, there are often intriguing differences in the detail. For instance, there is evidence supporting the notion that women have historically not been preselected in safe seats. The differing electoral cycles are apparent in the Senate and House of Representative data, as is the historical under-representation of women. Labor leaders tend to have had a higher survival rate, at least in the short term, than their Liberal counterparts, while longer time periods are influenced by long serving Liberal Prime Ministers.
\end{abstract}

Keywords: survival, survival modelling, Kaplan-Meier, prime minister, opposition leader, Australian parliament, government

a Affiliation unspecified. ORCID iD: 0000-0003-0983-3407

${ }_{b}$ School of Mathematics and Statistics of Mathematics, University of New South Wales, Sydney, Australia. ORCID iD: 0000-0002-1856-0538

Corresponding author: b.kachoyan@unsw.edu.au 


\section{Survival modelling of Australian politicians}

\section{Introduction}

Is Australian federal politics in the midst of a febrile era of leadership change? Since the 2007 federal election, there have been six Prime Ministers (Rudd (\#1), Gillard, Rudd (\#2), Abbott, Turnbull, Morrison) and six Opposition Leaders (Nelson, Turnbull, Abbott, Bowen, Shorten, Albanese). In Australia, the selection of party leaders lies in the hands of the parliamentary party and historically leaders have been appointed and removed in an almost "Darwinian" process (Gauja 2014). Prime Ministers can be removed without an election, and a leadership challenge, even when unsuccessful, can often be the start of a Prime Minister's downfall (Weller 1994).

The survival of a member of parliament, whether in the House of Representatives (HOR) or the Senate, is by definition less fraught than that of the leaders, given that you need to be a member of parliament to be Prime Minister (PM) or Opposition Leader (OL). Parliamentary tenure usually starts and finishes at an election (general or by-election), although parliamentarians may leave for a variety of reasons between elections, and in the Senate, may be appointed without election.

This article will examine the survival curves of various cohorts of Australian parliamentarians to test several commonly held beliefs about their tenures. In general, survival curves describe the probability that an individual will survive a certain amount of time, where "survival" is defined according to the context of the problem. In our context, it means leadership or parliamentary tenure. There is considerable value in examining the whole survival curve in order to identify events that occur at specific times or in time ranges not available through simple statistical measures such as average length of tenure (Rich et al. 2010, Kachoyan and West 2016). This article will compare the survival of PMs and OLs, leaders of the Liberal Party of Australia and the 
Australian Labor Party (hereafter referred to as "Liberal" and "Labor" respectively), members of the HOR and the Senate, and male and female parliamentarians. The differences across political eras will also be considered to test the proposition that the current era of high PM turnover is unprecedented.

\section{Theory}

Leadership turnover since 2007 has created a popular view, not only in Australia but internationally, that leadership spills are an Australian "national sport" (Rudra 2018). Instability is seen as feature of modern Australian politics, and this gives rise to various societal beliefs, some with more connection to reality than others. For instance, the popular view that Labor leaders are rolled in short order is probably due to the high turnover of Labor leaders, mostly in New South Wales state politics, in the 2000s (Aarons 2010, Nicholls and Oakes 2010). There have been a number of PM changes on both sides of politics in the recent past, and OLs have had the longer tenures, a marked difference to the 1990s. However, as attaining the Prime Ministership is the ultimate goal of an OL, one might have expected the power of incumbency to increase a PM's survival over the OL. Survival analysis allows us to look more closely at these phenomena.

There are various possible reasons why we have seen such a high PM turnover in the recent past. Parties are becoming increasingly "presidentialized" (Gauja 2015) and politics increasingly "candidate-centred" (Wattenberg 1991). Representatives transmit their political missives instantly through social media, but being more visible than ever before comes with vulnerability, with their survival tied more to their individual popularity than performance (McAllister 2003). And with a dwindling differentiation between their major policy platforms, Labor and Liberal are increasingly fighting battles over totemic issues like climate change, attempting to minimise gaffes 
and win popularity through sounds-bites in the 24-hour news cycle. Leadership turmoil is an outcome of this cycle.

The Senate and the HOR, despite being housed in the same building, have distinctive cultures and tasks, and are elected by separate voting methods. It is plausible that, with the comparatively lower thresholds for election to the Senate due to proportional voting, it is easier to be elected to the Senate given party endorsement than to the HOR, especially if listed in the first or second spot on your party's ticket; in the Senate you need to satisfy your party (and your factions) while in the HOR you need to appease your constituency (Brenton 2009). Senate candidates also have significantly different personal and political backgrounds to their HOR colleagues (Farrell and McAllister 1995). By Westminster convention, PMs and OLs sit in the HOR, where members engage in the theatrical cut and thrust of political battle. The only PM from the Senate, Sir John Gorton, resigned his Senate position after becoming PM and was elected as a member of the HOR. The HOR and Senate are therefore two quite different places, and these factors, along with the extended electoral cycle of the Senate, could lead to speculation that Senate tenure is more stable than HOR tenure. Furthermore, the effect of safe versus marginal seats and the power of incumbency might lead to speculation that the hazard rate (that is, the rate at which they leave parliament) would decrease over time until a natural retirement period is reached. Conversely, some studies have found a constant hazard (Casstevens and Denham III 1970). Through survival analysis we will test these hypotheses.

There is also a popular belief that women tend not to be pre-selected in safe seats (Chau 2016), and survival analysis allows us to test this idea. Women have historically been underrepresented in international parliaments, facing barriers to entry and internal promotion opportunities. For example, for ministers in three Westminster 
countries (Australia, Canada and New Zealand) between 1949-2012, it was found that women experience a significantly lower rate of cabinet promotion than their male counterparts (Curtin, Kerby, and Dowding 2014). One of the disadvantages for women in Westminster systems is the tradition of single-member electorates. Multimember electorates facilitate women's and minority representation, giving parties an incentive to construct tickets appealing to all sections of the community. Women have generally been better represented in houses of parliament elected by proportional representation than in those elected from single-member constituencies (Sawer, Tremblay, and Trimble 2006).

Internationally, some studies on female parliamentary survival have been undertaken. For ministers in the Quebec Executive Council between 1976 and 2012, ministerial careers of women follow a similar trajectory to that of men and are not any less illustrious (Tremblay et al. 2015). Other studies in this regard include a study of the Italian post-war parliament, in which the parliamentary survival of women was much greater than that of men for the period from 1946 to 2010. However, after splitting the epoch into two, it was found that gender is significant for survival only in the second era when most parties had adopted quotas for women (Fedeli and Forte 2011). Similarly, for ministerial tenure in the UK from 1945-1997, female ministers have lower hazard (higher survival) (Berlinski, Dewan, and Dowding 2007).

\section{Modelling Details}

These types of problems are commonly addressed using Kaplan-Meier (KM) estimators, more commonly known as the Product Limit Estimator (PLE) (Kaplan and Meier 1958, Klein and Moeschberger 2003). An important property of the PLE is that it is nonparametric; the PLE only uses the data to generate an estimate of the "true" underlying survival function, although attempts can be made to derive theoretical survival curves 
(Kachoyan and West 2018). It allows for more reliable inferences from the data about political processes than parametric models (Golub 2008). This technique has been used across many fields of endeavour with broad applicability. Some recent relevant examples in the political sphere include: a study of the survival of members of the Italian Parliament (Fedeli and Forte 2011, Borghetto and Visconti 2015); the turnover rate of individual cabinet members in the Netherlands from 1946 to 2010 (Bovens, Brandsma, and Thesingh 2015); the waiting time to become a minister in Canada (Kerby 2009), and Canadian federal cabinet ministerial appointment and exit (Kerby 2011); cabinet careers and gender in Australia, Canada and New Zealand (Curtin, Kerby, and Dowding 2014); the mortality risk of heads of government compared to candidates who never served (Olenski, Abola, and Jena 2015); American Congressional tenure survival modelling (Scully 1995); Ministerial tenure in the UK (Berlinski, Dewan, and Dowding 2007); the tenure of central bank governors (Ennser-Jedenastik 2014).

An important advantage of the PLE method is that it can take account of censored data in a relatively straightforward manner and hence is a more appropriate approach than least squares regression (Kerby 2009). In general, censored data refers to an individual leaving the observable data set after surviving for a certain period and without being observed to fail. A censored data point in the context of parliamentary survival analysis would refer to either careers that are still extant at the time the modelling was undertaken, or a parliamentary career where the cause of "death" (that is, how it ended) is not one we consider a failure. We have been conservative in our censoring in that only parliamentarians who died in office or who, with specific reference to PMs and OLs, were caretakers were assumed to have had censored careers. PMs who died in office were Lyons, Curtin and Holt, and caretaker PMs were Page, 
Forde and McEwen. OLs who died in office were Tudor and Chifley, and the only caretaker OL was Bowen. Even though we know that Australia's longest serving PM, Robert Menzies, left parliament of his own volition, for consistency we have not censored his career. Naturally, all representatives who were still in parliament at the time of study have not concluded their careers and so have censored tenures.

It is not at all simple to determine whether a parliamentarian voluntarily retired or whether they were coerced by colleagues. A good example of this dilemma is that of Herbert Evatt exiting the Labor leadership. His age and health became a concern and his exit, to be Chief Justice of the New South Wales Supreme Court, was stage-managed by Labor powerbrokers. This is largely regarded as giving him a dignified parliamentary exit (Bynander and 't Hart 2007). Is this a voluntary, and therefore censored, exit? It is difficult to tell, hence our conservatism in not assuming anything about the conclusions of careers. Our approach to censoring is similar to previous work which did not attempt to determine if a portfolio change in a study of Westminster systems was a promotion (Curtin, Kerby, and Dowding 2014).

In Australia, the OL is defined as the leader of the party not in government that has the most seats in the HOR (Parliamentary Education Office 2018a). An OL who ascended to the position of PM is considered to have had a censored career as OL; becoming PM is indeed the goal of an OL and they have not been ousted from their job due to failure.

The probability of survival as a function of time, or the probability that the survival time $t$ of an individual exceeds a certain value, is given by $S(t)=\boldsymbol{P}(\boldsymbol{T}>\boldsymbol{t})$, where $T$ is the survival time. The formulation of the PLE is based on the conditional probability that an individual dies (or in our case, ceases being PM or OL, or leaves parliament) in the time interval from $t_{i}$ to $t_{i+1}$, given survival up to time $t_{i}$, which is 
estimated as $d_{i} / n_{i}$, where $d_{i}$ is the number who die at time $t i$, and $n_{i}$ is the number alive just before time $t$, including those who will die at time $t$. The formulation is intuitive and fairly easy to calculate:

$$
S(t)=\prod_{i=0}^{t} \frac{n_{i}-d_{i}}{n_{i}}
$$

which can be expressed recursively:

$$
S\left(t_{i} \leq t<t_{i+1}\right)=S\left(t_{i-1} \leq t<t_{i}\right) \frac{n_{i}-d_{i}}{n_{i}}
$$

Without censoring, the PLE at any given time is simply the number still alive divided by the number originally in the sample. The use of the recursive formulation (2) makes it easier to visualise the effect of censored data. The PLE survival estimator is piecewise constant with discontinuities at the times of death and appears as a step function. The PLE approaches the true survival function for that population as the sample size increases and provides a visual depiction of all the raw data. The reduction of the sample size at large values means that the effect of each individual death on the size of the step-down increases and the accuracy of the estimate decreases. The PLE gives no prediction of performance beyond the largest data point if the longest time period is censored.

Our data has been collated from various sources (Department of Parliamentary Services 2017, McCann 2016, Bynander and 't Hart 2007, Parliamentary Education Office 2018a, b). The PM and OL data have been updated to 31 May 2019, while the HOR and Senate data is updated to 11 July 2017. Some manipulation of the source data was required due to quirks in the Australian parliamentary system, mostly in the Senate. For example, the term of service of a Senator from the Australian Capital Territory or the Northern Territory expires at the close of the day preceding the polling day for the 
general election of members of the HOR (Department of Parliamentary Services 2017). Hence it appears that, even when continuing after successful re-election, their Senate terms have breaks. We have assumed that Territorian Senators have continuous service where they have won at re-election. Other quirks include that of Nancy Buttfield, who resigned her Senate position one day before the 1961 election conditional upon her election on that date as a Senate candidate (Biographical Dictionary Unit; Research Section of the Australian Senate 2010). Her tenure has also been considered continuous. There are cases where a Senator had been filling a casual vacancy at the time of an election, with their successful re-election only taking effect at some later point and hence there was a break between their terms of service (e.g. Tom Drake-Brockman). In this case, their service is considered as separate stints. There are relatively few cases of this occurring, and this has not been a feature of parliament since 1977, when a successful referendum established that the term of a Senator filling a casual vacancy would continue until the end of the original senator's term, as opposed to the next general election (Department of Parliamentary Services 2017). Individuals who have served more than once (for example Kevin Rudd or Robert Menzies as PM, or Janine Haines or John "Sandy" MacDonald as Senators) are considered as having separate lifespans.

The logrank test is a popular statistical test to compare the survival curves of two groups (Bland and Altman 2004). The logrank test is used to produce $p$-values, which have traditionally been used to help describe the probability that multiple data sets come from the same population, hence helping the analyst make a call on whether the data sets are different. However, recent debate (known colloquially as the "statistics wars") suggests that $p$-values are highly vulnerable to misinterpretation and misuse (Amrhein, Greenland, and McShane 2019, Wasserstein, Schirm, and Lazar 2019). With 
regards to the work of this article, attempting to compare two survival curves using a single $p$-value without looking at the curves themselves would overlook the interesting differences between the curves that may occur within particular time intervals because of interesting reasons, in a similar way to how a simple average clouds details about the spread of data in a data set. Obtaining statistical significance with a small sample size can also be difficult. Care must be taken not to ascribe reason to noise in the data, however observation of the whole survival curve allows us to tease out intriguing facets of the minutiae. $P$-values have been quoted for rigour, but they have not been used in and of themselves to draw conclusions.

\section{Results}

\section{Prime Ministers and Opposition Leaders}

Figure 1 compares the survival curves of PMs and OLs and shows that while OLs have a greater short-term survivability, PMs have a higher capacity for very long tenures; clearly, there may be little point in keeping an OL who has been unsuccessful at multiple elections. Somewhat counterintuitively, OLs out-survive PMs to about six years, and over $20 \%$ of PMs do not survive a year, a result driven largely by events early in Federation. After about three years in office, PM survival improves, suggesting that success at their first election is important for a PM's survival. There is a cluster of PM-careers around seven years, beyond which the curve is dominated by the three longest serving PMs: the Bradman-like Menzies term, the Bradman-light Howard term and the Bradman-Museum-patron Hawke term (Bradman Foundation 2014, Hutchins 2009, Wade 2019). The biggest danger zone for an OL seems to be around two to three years, with another dip around six years, mirroring the electoral cycle. The most recent uncensored OL, Bill Shorten, survived just short of six years, a period of two elections. 
One explanation for the elevated short-term survival of OLs is that if they are successful in their position, they are elevated to the role of PM at election and therefore have censored OL careers. This has the effect of increasing the short-term values of the OL survival curve, while the curve dips when it becomes apparent that longer-term OLs are not successful and are replaced. The $p$ value comparing the curves is 0.66 .

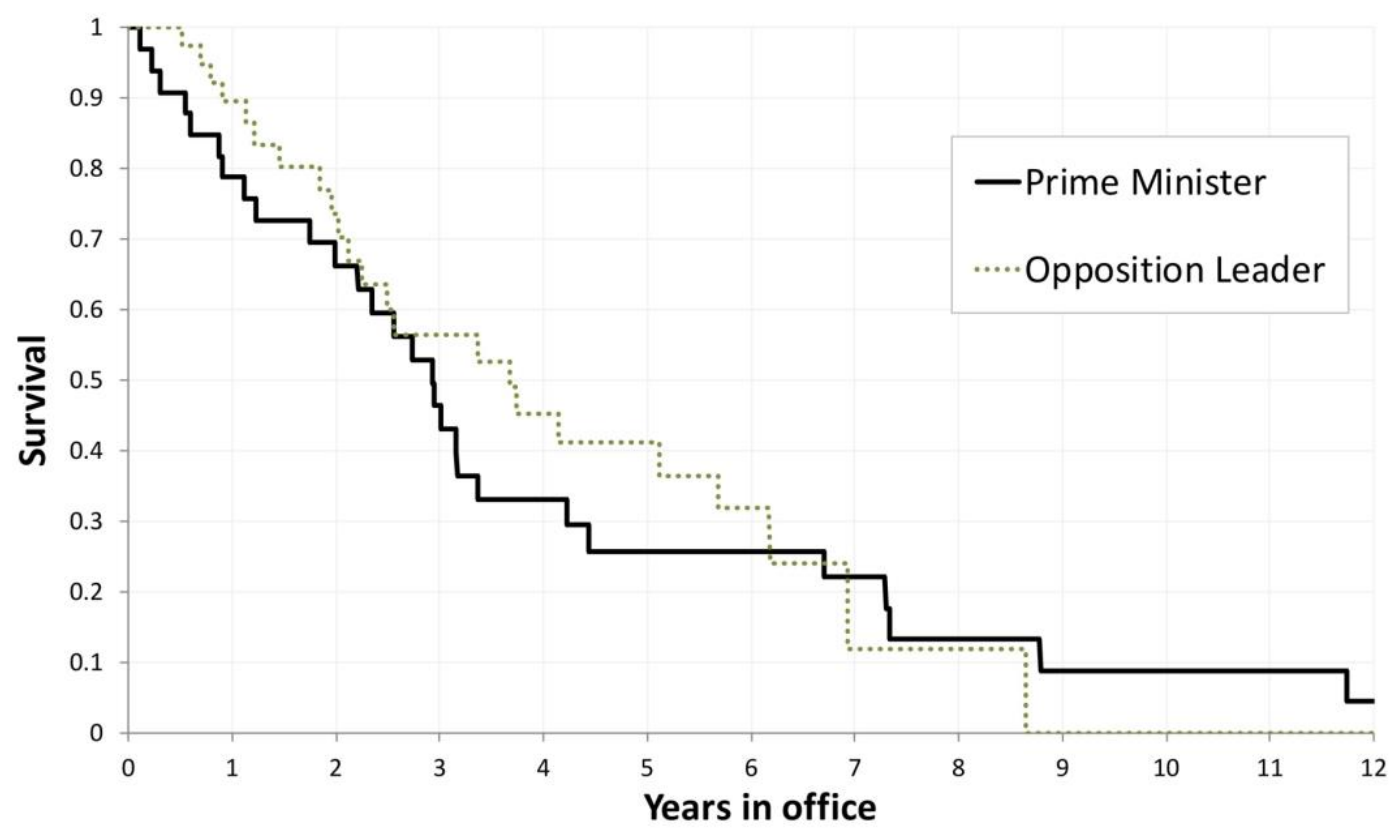

Figure 1. Survival curves for the Prime Minister and Opposition Leader.

\section{Labor and Liberal Leaders}

Figure 2 depicts the Labor (since 1901 - 25 leadership terms) and Liberal (since 1945 17 leadership terms) leadership survival curves, irrespective of whether they are in Government or Opposition. Liberal leadership is only analysed since 1945 as this is when the party was launched, formed by the merger of the United Australia Party with other conservative and anti-Labor groups (Hancock 1994). Contrary to the "NSW disease" view of Labor leadership (Aarons 2010, Nicholls and Oakes 2010), Figure 2 suggests that federal Labor leadership is historically more stable than federal Liberal leadership, at least in the short-term, with double the chance of surviving more than five 
years. The parties do not have the same level of survival till about nine years, after which the Liberal curve is dominated by Menzies and Howard. The survival of the Labor leader decreases almost linearly out to zero at 11 years. The $p$-value is 0.45 .

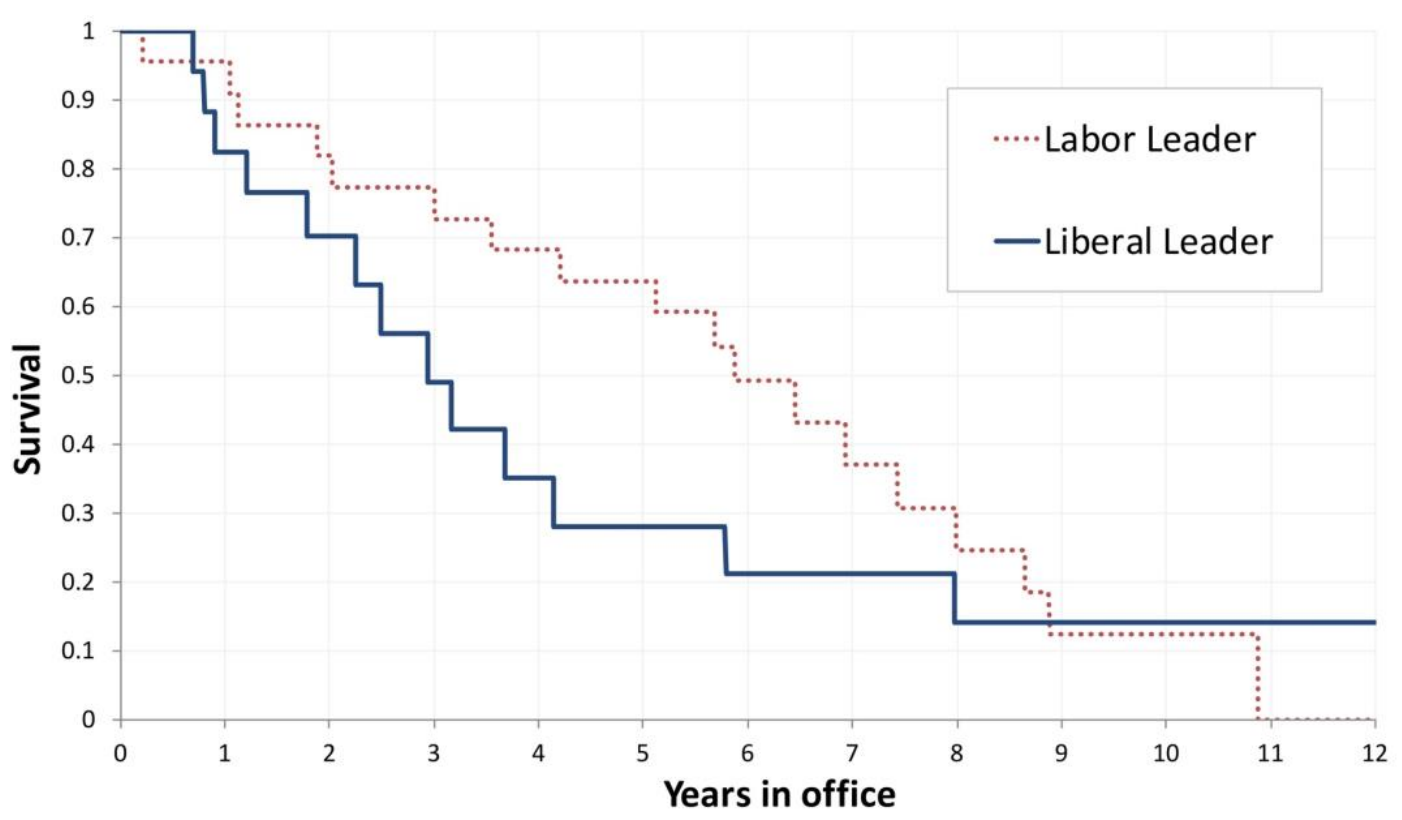

Figure 2. Survival curves for Labor Party (since 1901) and Liberal Party (since 1945) leaders.

\section{House of Representatives and the Senate}

Figure 3 compares the survival curves for members of the HOR and the Senate and shows that intriguingly there is not much overall difference between the survival curves $(p=0.70)$, even though they are very different places with different electoral cycles. Again, there are some interesting differences in the detail worth examining. As expected, once can see the influence of the two electoral cycles, three years for the HOR and six years for the Senate, although the effect is smeared somewhat in the HOR due to the general elections not having to be held at exactly three year intervals. The HOR is more stable in the first three years, until the first election. As Senators are elected for six years, they do not face election at the same time as the HOR and hence the Senate 
survival curve does not markedly change at three years. The regular drops at six year intervals in the Senate curve are expected given the predictable Senate electoral cycle; these drops are sharper than the three year drops in the HOR. Note that Territorian senators have terms the same tenure length as members of the HOR (not fixed six year terms like the states). This has a small smoothing effect on the Senate curve.

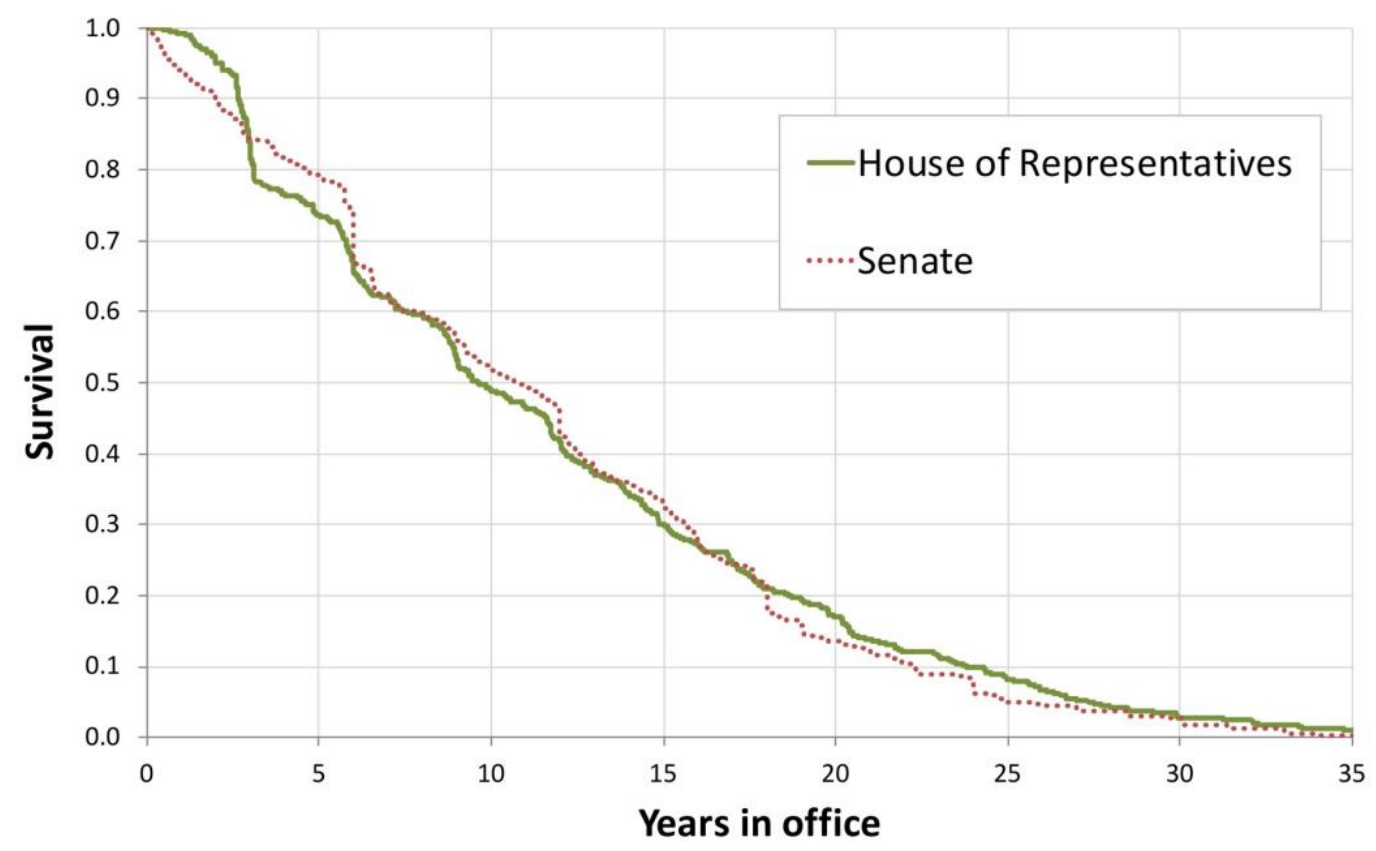

Figure 3. Survival curves for members of the House of Representatives and members of the Senate.

Figure 4 shows the same HOR and Senate survival results using a logarithmic scale. That presents a slightly different view which brings out some of the more detailed differences between the curves. For example, a straight line would imply a constant hazard, however both the Senate and HOR survival curves have a continuously increasing hazard (the curves turn downwards) as a parliamentarian's career progresses. This is consistent with previous work that suggested a weariness after a long career following an early honeymoon period which benefited from incumbency (Finocchiaro 
and Lin 2000). There is, however, a surprising linearity in the curve for the Senate in the initial six-year period implying there is a hazard for senators even before the first reelection opportunity. The logarithmic plot in Figure 4 also more explicitly shows the diverging curves after about 18 years, at which point Senate survival drops below HOR survival. It may be that the HOR has a higher hazard at less than 18 years due to its dynamism and increased opportunity for electoral defeat, but it has a slightly increased incumbency benefit over the Senate beyond this time.

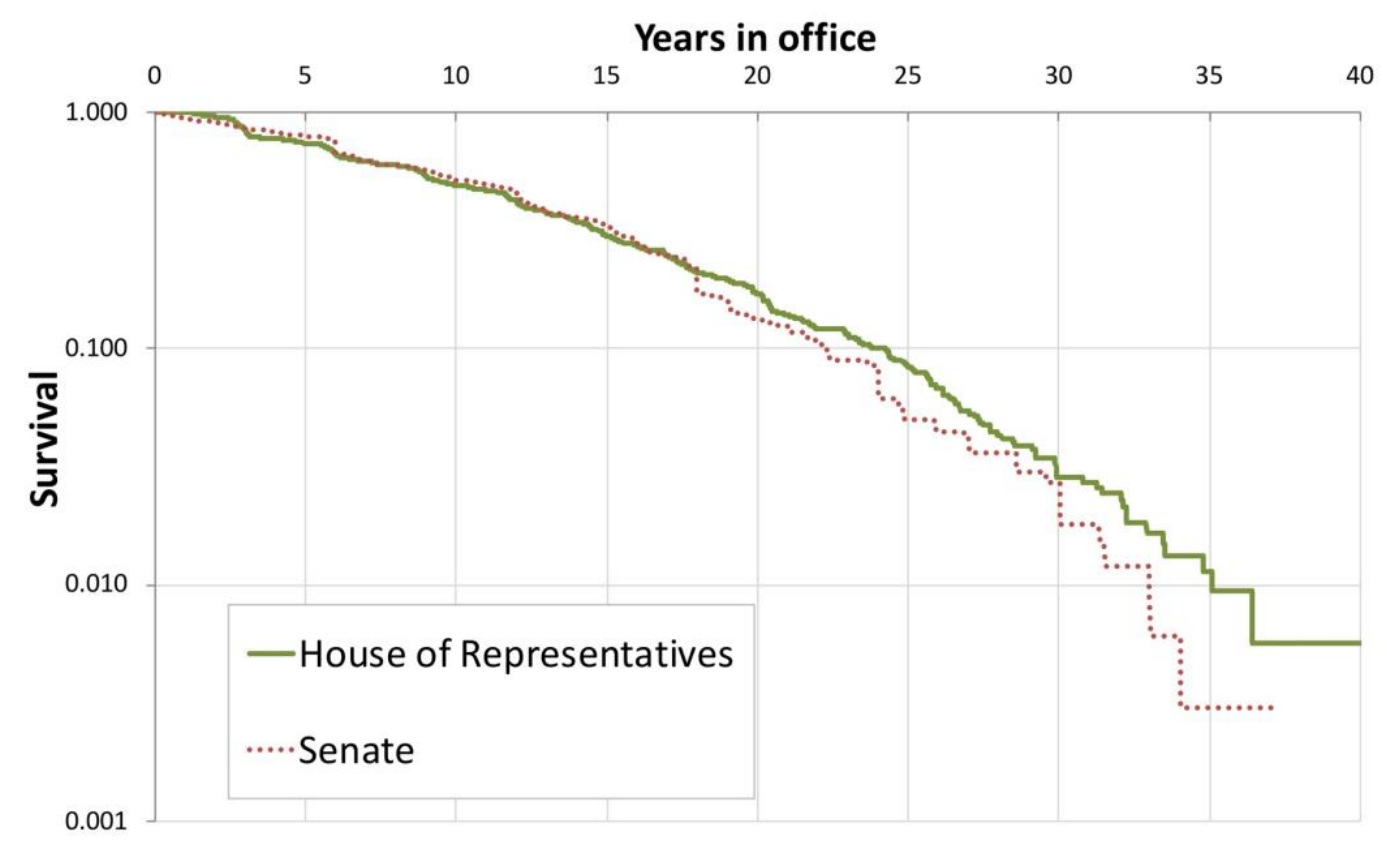

Figure 4. Survival curves for members of the House of Representatives and members of the Senate with logarithmic survival scale.

\section{Women in Parliament}

A question of interest is whether there is any difference in the careers of males and females in parliament. The survival curve results are shown in Figure 5 for the Senate and Figure 6 for the HOR. It should be noted that the number of female tenures in the HOR is less than 10 percent of the males; hence the male-only curve is largely indistinguishable from that in Figure 3. While the Senate is still dominated by men, the 
difference is not as large (females are roughly 20 per cent of the male population), reflecting the notion that women have generally been better represented in houses of parliament elected by proportional representation rather than single-member constituencies (Sawer, Tremblay, and Trimble 2006). Our study suggests little overall difference between the survival of men and women in both houses $(p=0.56$ in the Senate, $p=0.73$ in the HOR) although once again there are interesting differences in the detail. The sharper features of the female curves, especially in the HOR (Figure 6), are partly due to the smaller sample size. While the survival for men at very long tenures may be higher than for women, women have been historically under-represented in parliament and hence have had less opportunity for long tenures. Interestingly, the survival of women out to 12 years in both curves is higher than for men, before a period of similar survival and then the long tenured men. There is no evidence to suggest that overall women have shorter parliamentary careers.

The following figures provide some confirmatory evidence towards the hypothesis that women tend not to be pre-selected in safe seats. This can be seen in the larger decrease in survival in the HOR (Figure 6) at the three-year mark for females than males; female survival past one election is more tenuous than male survival. One further explanation for this is that long-serving members of the HOR tend to be in safe seats, and these members tend to be male. It may be that over time, as long-standing members retire, this effect dissipates (Raue 2018). The results shown in Figure 5 and Figure 6 are broadly in line with other studies using survival modelling techniques to examine parliamentary survival (Tremblay et al. 2015, Fedeli and Forte 2011, Berlinski, Dewan, and Dowding 2007). 


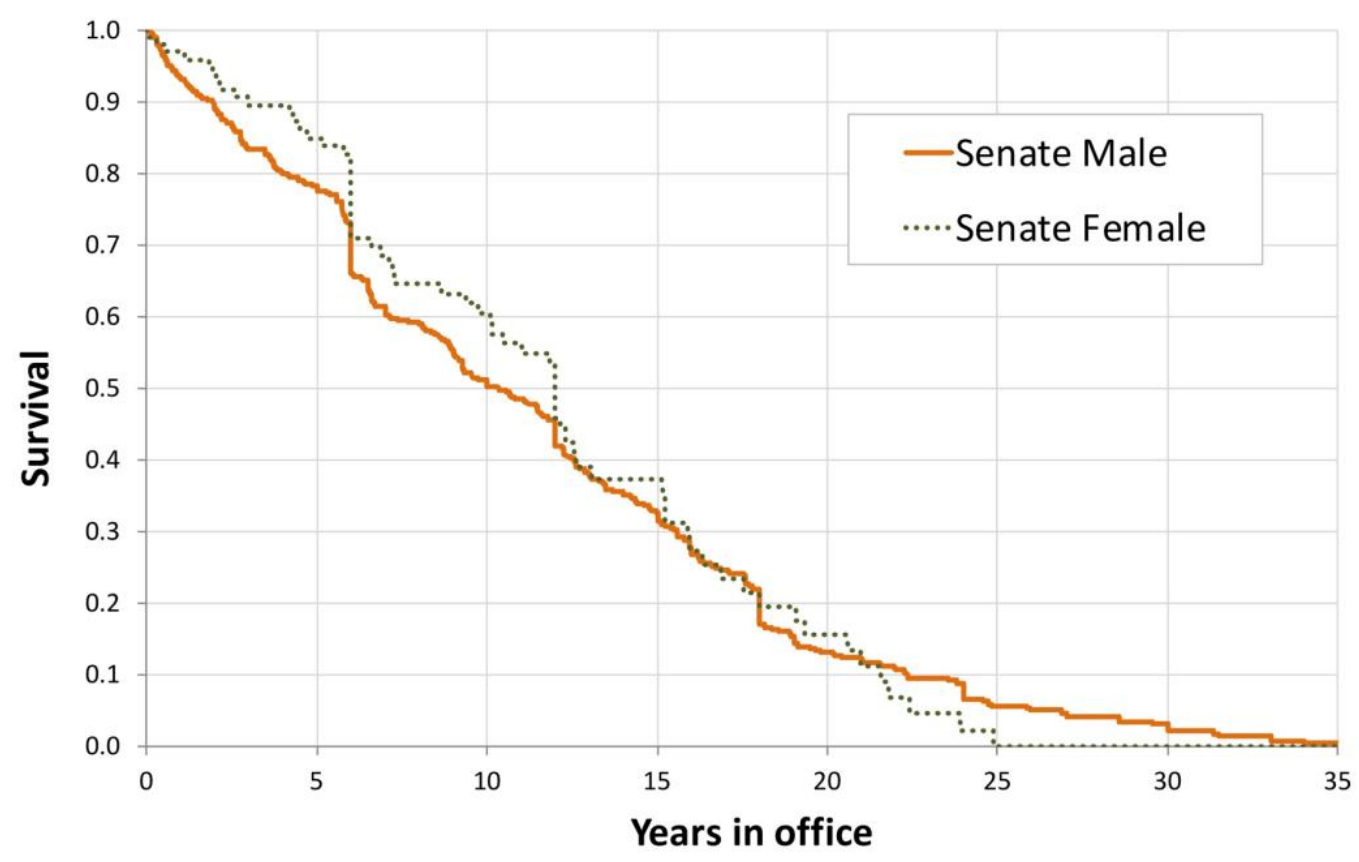

Figure 5. Survival curves for male and female members of the Senate.

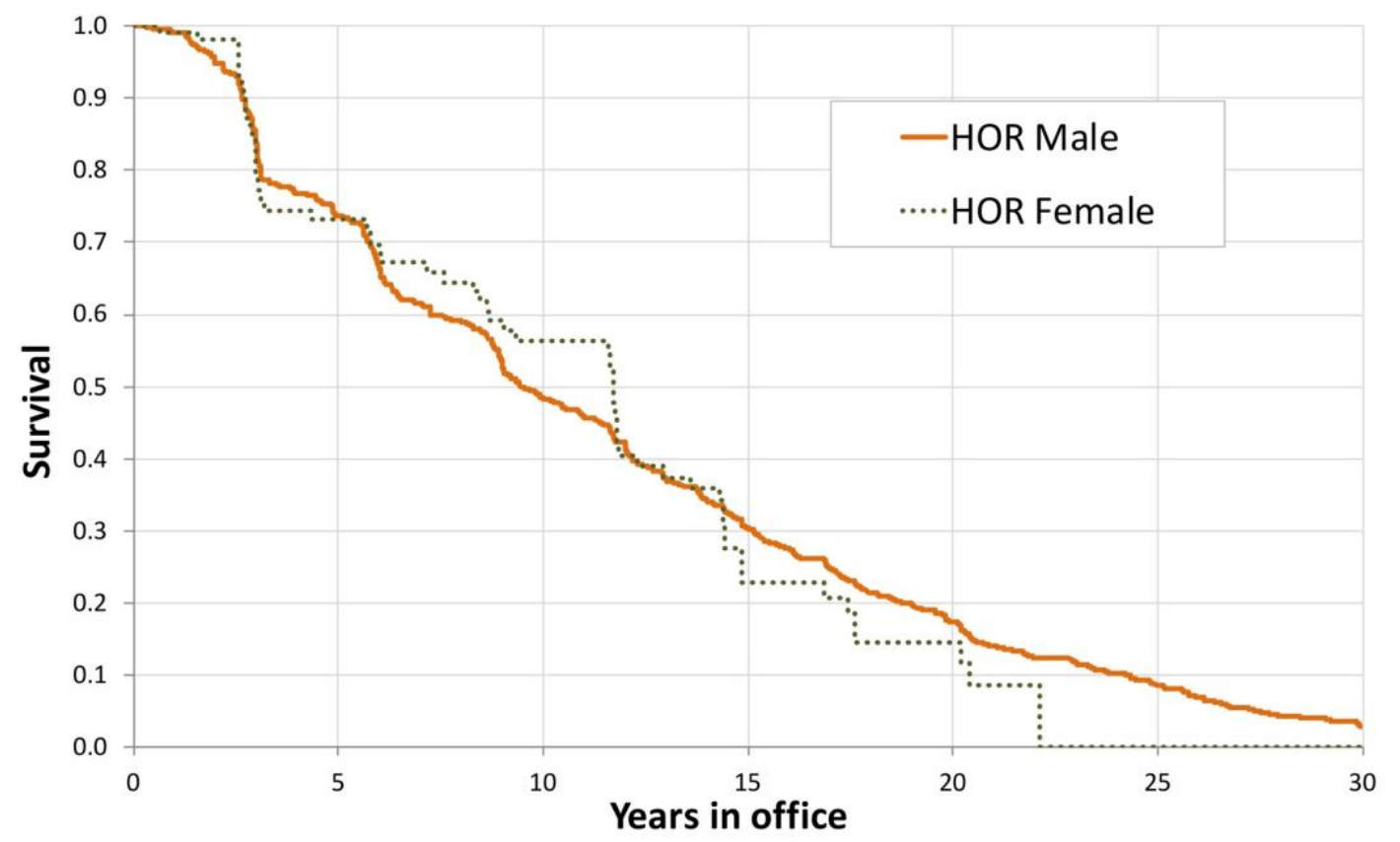

Figure 6. Survival curves for male and female members of the House of Representatives. 


\section{Summary Statistics}

Table 1. Descriptive Statistics of the cohorts studied in this article.

\begin{tabular}{|c|c|c|c|c|}
\hline \multicolumn{2}{|l|}{ Cohort } & Sample Size & $\begin{array}{c}\text { PLE Median } \\
\text { (years) }\end{array}$ & $\begin{array}{c}\text { PLE Average } \\
\text { (years) }\end{array}$ \\
\hline \multicolumn{2}{|l|}{ Prime Minister } & 36 & 2.9 & 4.1 \\
\hline \multicolumn{2}{|l|}{ Opposition Leader } & 45 & 3.7 & 4.1 \\
\hline \multicolumn{2}{|l|}{ Liberal Leader } & 17 & 2.9 & 4.9 \\
\hline \multicolumn{2}{|l|}{ Labor Leader } & 25 & 5.7 & 5.6 \\
\hline \multirow{3}{*}{$\begin{array}{l}\text { House of } \\
\text { Representatives }\end{array}$} & Member & 1395 & 9.7 & 11.6 \\
\hline & Male & 1277 & 9.4 & 11.6 \\
\hline & Female & 118 & 11.7 & 10.9 \\
\hline & Member & 649 & 10.7 & 11.5 \\
\hline \multirow[t]{2}{*}{ Senate } & Male & 547 & 10.3 & 11.4 \\
\hline & Female & 102 & 12.0 & 11.9 \\
\hline
\end{tabular}

Table 1 shows the PLE medians and averages for the various cases we have examined.

These statistics are different to standard medians and averages due to the special treatment of the censored data. The PLE median is the time at which there is 50 per cent survival, while the PLE average is the area under the survival curve. The PLE average shows little difference between PM and OL; this average has hidden the differences that are obvious when observing the whole survival curve, with the long serving PMs increasing the average PM term without making any difference to the median. A similar effect is seen with the Liberal leadership statistics. The Labor leader PLE average and median are about the same due to the linear nature of its survival curve. In most of the cases in Table 1, the PLE median is less than the PLE average, because some very long tenures increase the averages and thus give a misrepresentation of parliamentary survival. Two exceptions to this are women in both houses of parliament. This arises from the fact that a large proportion of women who have ever been in parliament are currently still there due to their historical under-representation, hence their careers are 
censored. Additionally, there have not been many women with long tenures compared to men.

\section{Eras of Australian Politics}

Table 2 shows four political eras since 1901, an era defined for this article as having 10

PM terms. Figure 7 shows the survival curves for PMs for each of those eras.

Table 2. Political eras in Australia based on 10 Prime Ministers per period.

\begin{tabular}{|c|c|c|c|c|c|c|}
\hline Era & Name & Period & Years & Prime Ministers & PMs & OLs \\
\hline 1 & Early & $\begin{array}{l}1 \text { January } 1901 \text { - } \\
27 \text { October } 1915\end{array}$ & 14.8 & $\begin{array}{l}\text { Barton, Deakin (\#1), Watson, Reid, } \\
\text { Deakin (\#2), Fisher (\#1), Deakin } \\
(\# 3), \text { Fisher (\#2), Cook, Fisher (\#3) }\end{array}$ & 10 & $\begin{array}{c}11 \\
\text { (one overlaps } \\
\text { below) }\end{array}$ \\
\hline 2 & Wartime & $\begin{array}{l}27 \text { October } 1915- \\
19 \text { December } 1949\end{array}$ & 34.2 & $\begin{array}{l}\text { Hughes, Bruce, Scullin, Lyons*, } \\
\text { Page**, Menzies (\#1), Fadden, } \\
\text { Curtin*, Forde**, Chifley }\end{array}$ & 10 & $\begin{array}{c}9 \\
\text { (one overlaps } \\
\text { above) }\end{array}$ \\
\hline 3 & Post-war & $\begin{array}{l}19 \text { December } 1949 \text { - } \\
3 \text { December } 2007\end{array}$ & 58.0 & $\begin{array}{c}\text { Menzies (\#2), Holt*, McEwen**, } \\
\text { Gorton, McMahon, Whitlam, } \\
\text { Fraser, Hawke, Keating, Howard }\end{array}$ & 10 & 20 \\
\hline 4 & Modern & $\begin{array}{l}3 \text { December } 2007 \text { - } \\
31 \text { May } 2019\end{array}$ & 11.7 & $\begin{array}{l}\text { Rudd (\#1), Gillard, Rudd (\#2), } \\
\text { Abbott, Turnbull, Morrison*** }\end{array}$ & 6 & 6 \\
\hline
\end{tabular}

Stars indicate censored terms: * Died in office; ** Caretaker; *** Incumbent 


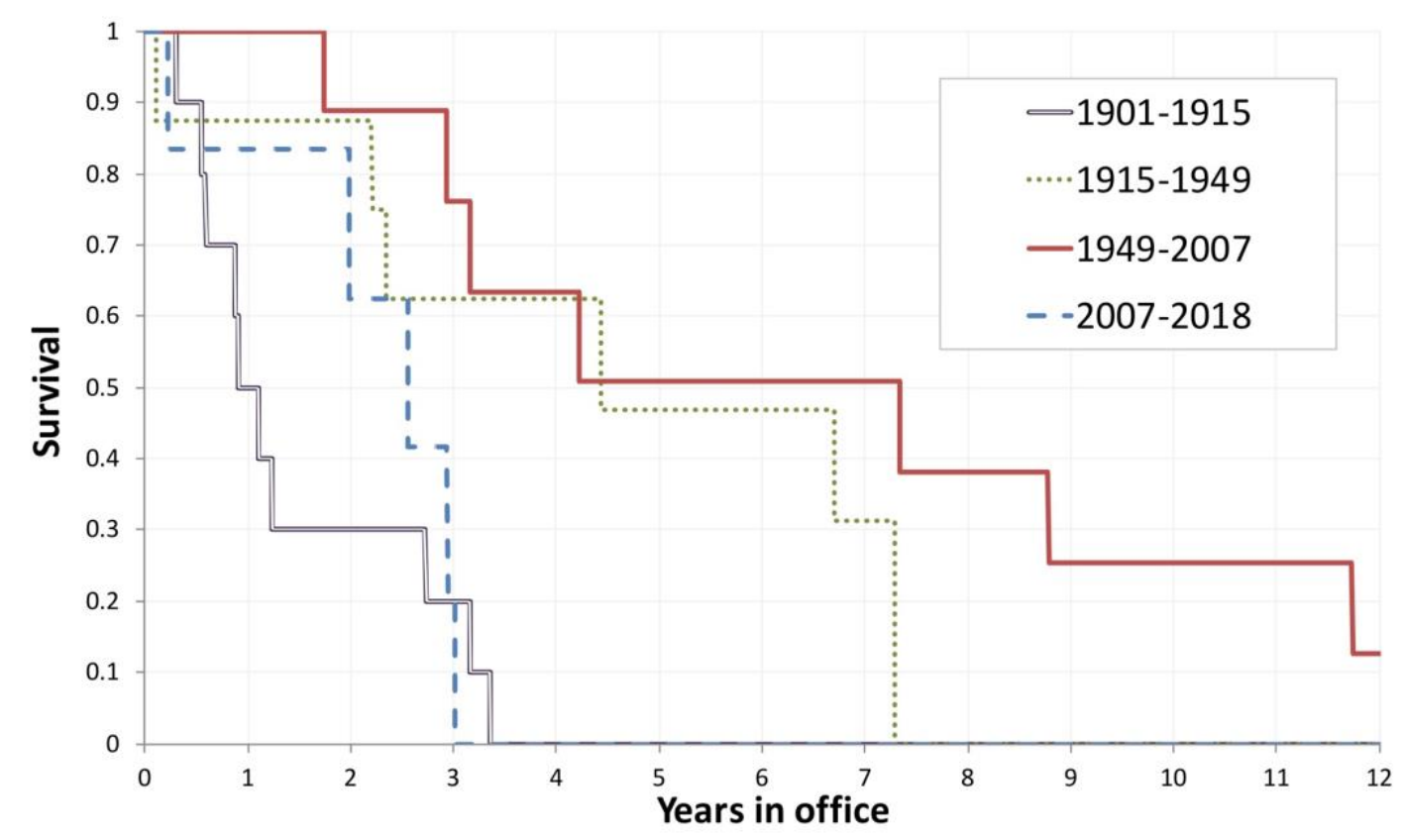

Figure 7. Survival curves for the Prime Minister in the four political eras, based on 10 Prime Ministers per era.

The choice of 10 PMs per period is somewhat for convenience, but it also natural as it allows the post-war era to commence with the lengthy second Menzies term, and the modern era to commence after the long Howard term with the shortened first Rudd term. It also results in the early parliament containing the three Fisher terms and highlights the fact that the modern era of leadership upheaval is not without precedent; however, something similar has not been seen since before 1915. Choosing eras by PM rather than time also avoids the technical complications of PM terms straddling eras.

Table 2 and Figure 7 suggest, the current rate of PM turnover is more like that of the early Australian parliament than that of the wartime or post-war eras; PM survival beyond three years is uncommon. The early era had multiple parties, parliamentarians switched sides, and governments were defeated on the floor of the parliament, meaning that PM survival dropped almost as soon as they were endorsed as PM; there was little honeymoon period. Comparing the survival curves of the eras, the modern era is 
somewhat similar to the early parliament $(p=0.59)$, and different from the wartime $(p=0.14)$ and post-war $(p=0.02)$ eras.

While parliamentary conditions are not the same as in the early parliament, we can postulate various reasons why the modern era has seen a high PM turnover. Citizen journalism and social media, as more politicians adopt its use (Grant, Moon, and Grant 2010), may be playing a significant role (McKinnon et al. 2016), continuing the greater political focus on PMs and OLs that television brought (McAllister 2004). Gaffes and simple mistakes are celebrated in real-time by journalists and social media followers. The "increasing leader-centeredness" and the "presidentialization of parties" may also be increasing parliamentary dynamism (Gauja 2015). This is also known as "candidatecentred politics", which has been rising for some time (Wattenberg 1991). Political leaders are more visible and accountable in the modern era than in the past, with their survival tied more to their individual popularity than government performance (McAllister 2003). This may be increasing their hazard compared to previous eras.

The increased focus on the individual politician feeds back into the notion that the Australian federal party system has become dominated by pragmatism and party leaders, making the maintenance of power more important than achieving the goals that power could bring (Marsh 2006, van Onselen and Errington 2016). This feedback is reinforced if the parties themselves are considered convenient homes for "independent political entrepreneurs" little different from ad agencies marketing their candidates for election like a product (Panebianco 1988). This "professionalization of politics" has led to a loss of diversity, which then results in a narrower outlook and smaller ideological drive. By lack of diversity, we refer to the fact that most parliamentarians are now career political workers or union leaders, as opposed to small-business owners and union members, the stereotypes that the parties might claim to represent. There has been 
a rise in diverse representation in other societal aspects (for example, gender and ethnicity) but this has not yet seen a demonstrable widening of ideology.

The Howard to Rudd (1), and Rudd (2) to Abbott, transitions are the only PM changes in the modern era to have occurred at an election, with the rest of the changes occurring because of internal party machinations at least partially based on popularity polling. This is tied to the rise in importance of individual popularity, but this factor may be about to diminish. The major polling errors ahead of the 2019 Federal Election (Schmidt 2019), along with the poor polling performance and the failure of betting markets seen in international examples such as Brexit and US President Donald Trump, could see parties less prone to changing leader because of poor opinion poll results.

A second issue influencing modern leadership turnover is climate change. Indeed, the modern era could be considered to have started with "the first climate change election" in 2007 , although predictions that this era might be defined by Australia playing "a leading role in global environmental politics" (Rootes 2008) have largely been overtaken by the "madness" of the current climate change debate (Hudson 2019). Certainly, a leader's position on, and policy response to, climate change and energy has been fundamental to their survival as leader (Fielding et al. 2012).

Another interesting factor within the modern era is that, in Julia Gillard, Australia had its first female PM, and with the issue of gender ever-present in politics (Stewart 2016), Gillard faced such internal (Labor) and external (media) pressures that her tenure as PM was ended not at a general election but in the party room (Williams 2017, Wright and Holland 2014, Sawer 2013). With female parliamentary participation generally rising, it remains to be seen how the next female federal Liberal or Labor leader fares and whether the conclusion to Gillard's Prime Ministership was genderbased, a symptom of the current dynamic era, or a combination of these and other 
factors. Even though, as shown earlier, female parliamentary survival curves are not particularly different from the male curves, there has only been one female leader of the federal Liberal or Labor parties, so there is not yet enough data to say anything about gendered leadership survival curves. Of the other major parties of the post-war and modern eras, the Australian Democrats have had six female leaders (out of 11) and the Australian Greens one (out of three) however neither party has filled the roles of PM or OL (Madden 2009). The number of women leading the Liberal and Labor parties at state level is also small, while The National Party of Australia has never had a female leader at federal level. More data is needed to draw further survival conclusions here. It also remains to be seen whether recent reforms introduced by Kevin Rudd (Labor) and Scott Morrison (Liberal) will influence leadership dynamics, as it is now much more difficult to remove a party leader than it was previously. The only way now to remove the Labor leader is for 60 per cent of caucus to sign a petition requesting a new election for leader when in opposition, and 75 per cent when in government. The new rules govern how the leader is selected, with a ballot of both the parliamentary Labor Party and rank-and-file members taking place (Chiru et al. 2015). The Liberal party now needs two thirds of the party room to remove a leader (Murphy and Karp 2018).

\section{Conclusions}

The current era of Australian politics is certainly dynamic, and it will be fascinating to watch whether it continues to resemble the early days of parliament and be different from previous eras with a series of short-termed PMs, or whether it's a mere coincidence or statistical blip. The early parliament was a very different environment to the modern day, with PMs often defeated on the floor of the parliament and a wide variety of influential parties. The modern parliament has its own unique challenges, and 
both parties would be hoping for some post-war era long-term PMs. The new rules surrounding leadership change in both major parties, a rising distrust of polling, the changing state and use of the media, policy response to climate change and the increasing possibility of more female leadership could add new dimensions to this survival analysis.

Similar leadership turnover has not been seen in New Zealand and Canada, and the recent churn of PMs in Great Britain is undoubtedly caused by Brexit machinations. On the surface, this suggests uniquely Australian factors at play, however this is not necessarily true. Despite a recent election win and being relatively popular, in September 2019 New South Wales Premier Gladys Berejiklian narrowly avoid a spill of her leadership. In this instance, it was clearly not as a result of polls, and likely not gender. The challenge emerged from the decades-old ideological battle between moderates and conservatives in the party, in this instance over an abortion bill. The party divide may be historical, but the example highlights the capacity of "single-issue or emblematic politics" (Marks 2019) to become the focus of political attention. While particularly evident in Australia (for example, climate change at the federal level), the idea of a single issue being a proxy for a broader battle is not uniquely Australian; Brexit is an obvious international example. Such battles may arise from the cartel model of modern parties where, with little polarising differences between the large professional parties, single issues are chosen as political battlegrounds (Katz and Mair 2009). In this instance, the fact that those threatening the spill came from particularly socially conservative electorates also suggests that parliamentarians may be acting to satisfy their electorate (who can agitate in real time through social media), and therefore their own survival, rather than the party position. 
Nevertheless, "street-by-street regionalism" (Marks 2019) works both ways. Parties are now able to target specific sections of society through social media advertising based on machine learning, with again Brexit and Trump being standout international examples. It is not yet resolved how influential these particular advertising campaigns were in the overall scheme of those elections, or whether the data was collected and used legally, but it is not in doubt that politicians will increasingly use data-driven micro-targeting as a political strategy, sending tailored information to individuals on topics important to them (Polonski 2017). If voters receive assurances on issues close to their hearts, they will hold politicians to account based on them, and the circle is complete. Having to respond constantly to criticism means shallower, riskaverse policy positions. Leadership churn is a symptom of this underlying cycle of proxy battles, "gotcha journalism" and the 24-hour news and response cycle (Murphy 2018).

This article has shown that survival analysis is a useful tool for examining the lifetimes of Australian parliamentarians, especially when considering the survival curves in their entirety. We have highlighted differences in the eras of Australian PMs, the survival curves of PMs and OLs, and of Liberal and Labor leaders. Statistical tests would suggest few differences between rank-and-file male and female parliamentarians, and between the House of Representatives and the Senate, however using the survival analysis technique, we are able to examine more subtle features of the survival curves, such as the impact of the electoral cycle, that are lost with simple averages and descriptive statistics. 


\section{References}

Aarons, M. 2010. "The hollowmen (The NSW ALP right faction and NSW state and Australian federal politics)." The Monthly August:22-28.

Amrhein, V., S. Greenland, and B. McShane. 2019. "Scientists rise up against statistical significance." Nature 567 (7748):305-307.

Berlinski, S., T. Dewan, and K. Dowding. 2007. "The Length of Ministerial Tenure in the UK 1945-1997." British Journal of Political Science 37 (2):245-262.

Biographical Dictionary Unit; Research Section of the Australian Senate. 2010. The Biographical Dictionary of the Australian Senate. Vol. 3. Sydney: University of New South Wales Press Ltd,.

Bland, J. M., and D. G. Altman. 2004. "The logrank test." BMJ 328 (7447):1073.

Borghetto, Enrico, and Francesco Visconti. 2015. "Governing by revising. A study on post-enactment policy change in Italy." In The Challenge of Coalition Government: The Italian case, edited by N. Conti and F. Marangoni. London: Routledge.

Bovens, M., G. J. Brandsma, and D. Thesingh. 2015. "This article investigated the turnover rate of individual cabinet members in the Netherlands from 1946 to 2010." Acta Politica 50 (2):127-150.

Bradman Foundation. 2014. ""United in Sport" - Former Prime Ministers Hawke and Howard join the Sport Australia Hall of Fame." accessed 7/6/2019. https://www.bradman.com.au/united-in-sport-former-prime-ministers-hawkehoward-join-the-sport-australia-hall-of-fame

Brenton, S. 2009. "What lies beneath: the work of senators and members in the Australian Parliament." Parliament of Australia, Department of Parliamentary Services: Australian Parliamentary Fellowship. https://www.aph.gov.au/About_Parliament/Parliamentary_Departments/Parliam entary_Library/pubs/APF/monographs/What_lies_beneath

Bynander, F., and P. 't Hart. 2007. "The Politics of Party Leader Survival and Succession: Australia in Comparitive Perspective." Australian Journal of Political Science 42 (1):47-72.

Casstevens, T. W., and W. A. Denham III. 1970. "Turnover and Tenure in the Canadian House of Commons, 1867-1968." Canadian Journal of Political Science 3 (4):655-661.

Chau, W. 2016. "Election Watch - Australia 2016: More women need to be pre-selected in safe seats." The University of Melbourne, accessed 12/6/2019. https://electionwatch.unimelb.edu.au/australia-2016/articles/more-womencandidates-need-to-be-selected-for-safe-seats

Chiru, M., S. Gherghina, A. Gauja, and J. R. Teruel. 2015. "Explaining Change in Party Leadership Selection Rules." In The Politics of Party Leadership: A CrossNational Perspective, edited by Jean-Benoit Pilet and William Cross. Oxford: Oxford University Press.

Curtin, J., M. Kerby, and K. Dowding. 2014. "Gender and Promotion in Executive Office. Cabinet Careers in the world of Westminster." European Consortium for Political Research, Joint Session Workshop: Gender, Prepresentation and Power in the Executive Branch, Salamanca, 10-15 April 2014.

Department of Parliamentary Services. 2017. 45th Parliamentary Handbook of the Commonwealth of Australia 2017: Commonwealth of Australia.

Ennser-Jedenastik, L. 2014. "Party politics and the survival of central bank governors." European Journal of Political Research 53 (3):500-519. 
Farrell, D. M., and I. McAllister. 1995. "Legislative recruitment to upper houses: The Australian senate and house of representatives compared." The Journal of Legislative Studies 1 (2):243-263.

Fedeli, Silvia, and Francesco Forte. 2011. The law of survival of the political class: an analysis of the Italian Parliament (1946-2010). University of Rome La Sapienza, Department of Public Economics.

Fielding, K. S., B. W. Head, W. Laffan, and M. Western. 2012. "Australian politicians' beliefs about climate change: political partisanship and political ideology." Environmental Politics 21 (5):712-733.

Finocchiaro, C. J., and T. Lin. 2000. The Hazards of Incumbency: An Event History Analysis of Congressional Tenure: Michigan State University, Institute for Public Policy and Social Research.

Gauja, A. 2014. "Leadership selection in Australia." In The Selection of Political Party Leaders in Contemporary Parliamentary Democracies, A Comparative Study, edited by Jean-Benoit Pilet and William Cross, 288. London: Routledge.

Gauja, A. 2015. "The Presidentialization of Parties in Australia." In The Presidentialization of Political Parties: Organizations, Institutions and Leaders, edited by Gianluca Passarelli, 160-177. London: Palgrave Macmillan UK.

Golub, J. 2008. "Survival Analysis." In The Oxford Handbook of Political Methodology, edited by Box-Steffensmeier J. M., H. E. Brady and D. Collier. Oxford: Oxford University Press.

Grant, W. J., B. Moon, and J. B. Grant. 2010. "Digital Dialogue? Australian Policians' use of the Social Network Tool Twitter." Australian Journal of Political Science 45 (4):579-604.

Hancock, I. 1994. "The Origins of the Modern Liberal Party." National Library of Australia, accessed 7/6/2019. https://www.nla.gov.au/ian-hancock/the-originsof-the-modern-liberal-party

Hudson, M. 2019. "'A form of madness': Australian climate and energy policies 20092018." Environmental Politics 28 (3):583-589.

Hutchins, B. 2009. "Social-conservatism, Australian politics and cricket: The triumvirate of Prime Minister John Howard, Sir Robert Menzies and Sir Donald Bradman." Journal of Australian Studies 25 (67):55-66.

Kachoyan, B., and M. West. 2016. "Cricket as life and death." 13th Australasian Conference on Mathematics and Computers in Sport, Melbourne.

Kachoyan, B., and M. West. 2018. "Deriving an exact batting survival function in cricket." 14th Australasian Conference on Mathematics and Computers in Sport, University of the Sunshine Coast.

Kaplan, E.L., and P. Meier. 1958. "Non-parametric estimation from Incomplete Observations." American Statistical Association Journal 53 (28):457-481.

Katz, R. S., and P. Mair. 2009. "The Cartel Party Thesis: A Restatement." Perspectives on Politics 7 (4):753-766.

Kerby, M. 2009. "Worth the Wait: Determinants of Ministerial Appointment in Canada, 1935-2008." Canadian Journal of Political Science 42 (3):593-611.

Kerby, M. 2011. "Combining the Hazards of Ministerial Appointment AND Ministerial Exit in the Canadian Federal Cabinet." Canadian Journal of Political Science 44 (3):595-612.

Klein, J. P., and M. L. Moeschberger. 2003. Survival Analysis: Techniques for Censored and Truncated Data. 2 ed: Springer-Verlag New York.

Madden, C. 2009. Australian Democrats: the passing of an era. Parliament of Australia, Politics and Public Administration Section. 
Marks, A. 2019. "NSW Premier Gladys Berejiklian avoids a spill but remains in troubled waters." The Conversation, accessed 18/9/2019.

https://theconversation.com/nsw-premier-gladys-berejiklian-avoids-a-spill-butremains-in-troubled-waters- 123676

Marsh, I. 2006. "Australia's political cartel? the major parties and the party system in an era of globalisation." In Political Parties in Transition, edited by I. Marsh, 1-23. Sydney: The Federation Press.

McAllister, I. 2003. "Prime Ministers, Opposition Leaders and Government Popularity in Australia." Australian Journal of Political Science 38 (2):259-277.

McAllister, I. 2004. "Political leaders in Westminister Systems." In Political Leaders and Democratic Elections, edited by K. Aarts, A. Blais and H. Schmitt, 52-75. Oxford University Press.

McCann, J. 2016. Traits and trends of Australia's prime ministers, 1901 to 2015: a quick guide. In Research Paper Series, 2015-2016: Parliament of Australia, Department of Parliamentary Services.

McKinnon, M., D. Semmens, B. Moon, I. Amarasekara, and L. Bolliet. 2016. "Science, Twitter and election campaigns: tracking \#auspol in the Australian federal elections." Journal of Science Communication 15 (6):A04.

Murphy, K. 2018. On Disruption. Melbourne: Melbourne University Press.

Murphy, K., and P. Karp. 2018. "Liberal party changes rules to require two-thirds majority to unseat sitting PM." Guardian, accessed 13/6/2019. https://www.theguardian.com/australia-news/2018/dec/03/liberal-partymorrison-changes-rules-to-require-two-thirds-majority-to-unseat-sitting-pm

Nicholls, S., and D. Oakes. 2010. "Keneally lashes out at Bligh's 'NSW disease' jibe." Sydney Morning Herald, accessed 11/6/2019.

https://www.smh.com.au/politics/federal/keneally-lashes-out-at-blighs-nswdisease-jibe-20100823-13imy.html

Olenski, A. R., M. V. Abola, and A. B. Jena. 2015. "Do heads of government age more quickly? Observational study comparing mortality between elected leaders and runners-up in national elections of 17 countries." BMJ 351:h6424.

Panebianco, A. 1988. Political parties: organization and power. Cambridge: Cambridge University Press.

Parliamentary Education Office. 2018a. "Leader of the Opposition." accessed 1/10/2018. https://www.peo.gov.au/uploads/peo/docs/factsheets/leader_opposition.pdf

Parliamentary Education Office. 2018b. "Prime Minister." accessed 1/10/2018. https://www.peo.gov.au/uploads/peo/docs/fact-sheets/prime_minister.pdf

Polonski, V. 2017. "How artificial intelligence conquered democracy." The Conversation, accessed 18/9/2017. https://theconversation.com/how-artificialintelligence-conquered-democracy-77675

Raue, B. 2018. "Women in parliament - still marginal." accessed 12/6/2019. http://www.tallyroom.com.au/34413

Rich, J. T., J. G. Neely, R. C. Paniello, C. C. J. Voelker, B. Nussenbaum, and E. W. Wang. 2010. "A practical guide to understanding Kaplan-Meier curves." Otolaryngology - Head and Neck Surgery 143 (3):331-336.

Rootes, C. 2008. "The first climate change election? The Australian general election of 24 November 2007." Environmental Politics 17 (3):473-480.

Rudra, N. 2018. "Leadership spill: How the world's media reported Australia's political crisis." Financial Review, accessed 19/9/2019. 
https://www.afr.com/politics/leadership-spill-how-the-worlds-media-reportedaustralias-political-crisis-20180810-h13twf

Sawer, M. 2013. "Misogyny and misrepresentation." Political Science 65 (1):105-117.

Sawer, M. , M. Tremblay, and L. Trimble. 2006. "Patterns and practice in the parliamentary representation of women." In Representing Women in Parliament, edited by M. Sawer, M. Tremblay and L. Trimble. London: Routledge.

Schmidt, B. 2019. "The mathematics does not lie: why polling got the Australian election wrong." Guardian, accessed 7/6/2019. https://www.theguardian.com/commentisfree/2019/may/20/mathematics-doesnot-lie-why-polling-got-the-australian-election-wrong

Scully, G. W. 1995. "Congressional tenure: Myth and reality." Public Choice 83 (3):203-219.

Stewart, E. 2016. "A matter of rights: the representation of women in the Museum of Australian Democracy." Journal of Australian Studies 40 (2):215-221.

Tremblay, M., D. Stockemer, R. Pelletier, and M. Kerby. 2015. "Les carrières ministérielles au Québec : Existe-t-il des différences entre les femmes et les hommes?" Canadian Journal of Political Science 48 (1):51-78.

van Onselen, P., and W. Errington. 2016. "Ruling, not governing: what to do about our lost confidence in the body politic." The Conversation, accessed 17/9/2019. https://theconversation.com/ruling-not-governing-what-to-do-about-our-lostconfidence-in-the-body-politic-52493

Wade, M. 2019. Tactics of the 'Ugly Australian': Morality, masculinity, nationalism and governance amid a cheating controversy in sport. In Journal of Sociology.

Wasserstein, R. L., A. L. Schirm, and N. A. Lazar. 2019. "Moving to a World Beyond "p<0.05"." The American Statistician 73 (51):1-19.

Wattenberg, M. P. 1991. The Rise of Candidate-Centered Politics: Harvard University Press.

Weller, P. 1994. "Party rules and the dismissal of prime ministers: comparitive perspectives from Britain, Canada and Australia." Parliamentary affairs 47 (1):133-143.

Williams, B. 2017. "A gendered media analysis of the prime ministerial ascension of Gillard and Turnbull: he's 'taken back the reins' and she's 'a backstabbing' murderer." Australian Journal of Political Science 52 (4):550-564.

Wright, K. A. M., and J. Holland. 2014. "Leadership and the media: Gendered framings of Julia Gillard's 'sexism and misogyny' speech." Australian Journal of Political Science 49 (3):455-468. 